\title{
Phylogenetic evaluation of cyanobacteria preserved as historic herbarium exsiccata
}

Correspondence

Katarzyna A. Palinska

k.palinska@uni-oldenburg.de

\author{
Katarzyna A. Palinska, ${ }^{1}$ Christian F. Thomasius, ${ }^{1}$ Jürgen Marquardt ${ }^{1}$ \\ and Stjepko Golubic ${ }^{2}$ \\ ${ }^{1}$ Geomicrobiology, ICBM, Carl von Ossietzky University of Oldenburg, 26111 Oldenburg, \\ Germany \\ ${ }^{2}$ Biological Science Center, Boston University, 5 Cummington Street, Boston, MA 02215, USA
}

\begin{abstract}
Dried herbarium specimens of cyanobacteria (exsiccata) deposited over 100 years ago were analysed and characterized using combined morphological and molecular approaches. Six representative coccoid and filamentous cyanobacteria from two historic collections and a 15-yearold air-dried environmental sample were studied. Morphological features observed by light and electron microscopy were correlated with the results of $16 \mathrm{~S}$ rRNA gene sequencing. Historic identifications achieved by means of classical morphology could thus be confirmed by extracted, amplified and sequenced $16 \mathrm{~S}$ rRNA gene fragments. The results of this study open the possibility of providing genotypic characterizations to botanical type specimens, thus reconciling the botanical and bacteriological approaches to the taxonomic treatment of these micro-organisms.
\end{abstract}

\section{INTRODUCTION}

The Cyanobacteria have diverse morphological, biochemical and physiological properties which have enabled this ancient group of micro-organisms to settle and persist in a wide range of habitats. Cyanobacterial diversity has been traditionally studied together with eukaryotic algae because these organisms co-occur in a variety of aquatic habitats and share the property of oxygenic photosynthesis. This property actually originated from within this group of prokaryotic phototrophs (e.g. Giovannoni et al., 1988; Wilmotte, 1994). Because of similarities in function and distribution, cyanobacteria have also been called blue-green algae, although their kinship with bacteria has long been recognized (Cohn, 1875). The name Cyanobacteria (Stanier, 1977) is now preferred as it better expresses their phylogenetic position as a separate division (phylum) among Gram-negative bacteria (Castenholz, 2001). Because of the relative structural complexity of many cyanobacteria, the group has been traditionally characterized and identified by morphological properties as revealed by light microscopy.

Systematic treatment of Cyanobacteria or Cyanophyceae is presently guided by two Codes of Nomenclature which were derived from historically separate traditions, were founded on different principles and which accordingly proscribe

\footnotetext{
Abbreviations: EPS, extracellular polymer substances; LM, light microscope/microscopy; SEM, scanning electron microscope/microscopy; TEM, transmission electron microscope/microscopy.

The GenBank/EMBL/DDBJ accession numbers for the 16S rRNA gene sequences determined in this study for the seven cyanobacterial species are shown in Table 1.
}

different treatments. Taxonomic treatment of cyanobacteria, including formal description of new taxa, can presently be carried out under the aegis of either of these codes. However, the rules of the Botanical and Bacteriological Codes are quite different and, when applied to the same group of organisms, confusions are unavoidable (Oren, 2004). For example, the Bacteriological Code requires live axenic type-cultures as the basic taxonomic reference, whereas the Botanical Code requires a fixed and preserved type reference. The two Codes have historically served different purposes; the Botanical Code was used for recording cyanobacterial diversity in nature whereas the Bacteriological Code was used for cultured micro-organisms in laboratories.

According to the botanical tradition, cyanobacteria have been distinguished on the basis of their phenotypic properties, including colony formation, cell morphology and extracellular envelopes, pigmentation, reproduction and, to a lesser extent, physiological and biochemical properties. At the heart of this tradition is the requirement that a newly described species be documented by a fixed, in most cases dried (exsiccatum) type specimen that is deposited in a herbarium collection to serve as the main taxonomic reference for later comparisons. Bornet \& Flahault (1886) and Gomont (1892a, b) wrote the first comprehensive manuals for the determination of filamentous cyanobacterial species. Phycologists recognize these sources as 'later starting points' in taxonomic referencing, primarily because of inherent difficulties in recognizing early descriptions which were often based on inadequate microscopic surveys. Others still support the principle of 
priority in resolving disputes in synonymy. In the 1930s, Geitler (1932) carried out a comprehensive, updated and widely used taxonomic revision. In his determination manual, he recognized 1300 species classified into 145 genera, 20 families and 3 orders. The manual for determination of cyanobacterial morphotypes recently published by Komarek \& Anagnostidis $(1999,2005)$ is a part of the same continuing tradition. Earlier historic resources are referenced there. Classical botanical taxonomy of cyanobacteria represents a body of work that has accumulated over the past 250 years since the introduction of the binominal naming system by Linnaeus in 1750. It has provided valuable information on the distribution and ecology of cyanobacteria. Culturing of cyanobacteria has been practised within this framework mainly to provide supplementary information.

In contrast, bacteriological taxonomy is based on axenic cultures and species are defined as groups of similar strains (Lapage et al., 1992). Bacteriological taxonomy of cyanobacteria was introduced in 1970s by Stanier (Stanier, 1977; Stanier \& Cohen-Bazire, 1977; Waterbury \& Stanier, 1977) and a proposal to place cyanobacteria under the rules of the Bacteriological Code of Nomenclature was submitted (Stanier et al., 1978). A determination key for cyanobacteria in cultures was designed soon after (Rippka et al., 1979). However, to date, only 13 cyanobacterial species have been proposed to the International Journal of Systematic and Evolutionary Microbiology (IJSEM)/International Journal of Systematic Bacteriology (IJSB) and, of these, only five have been accepted as valid (Oren, 2004). The current edition of Bergey's Manual of Systematic Bacteriology includes information compiled from both bacteriological and phycological sources (Castenholz, 2001).

Phylogeny has been the foundation of 'natural' systems in biology since Darwin, but until recently could not be applied to prokaryotes. Recent advancements in molecular biology that have enabled molecular sequencing and direct reading of the genetic code (e.g. Woese, 1987) have also provided an insight into phylogenetic interrelationships among microorganisms for the first time, including cyanobacteria. Work started with the analysis of axenic cultures of cyanobacteria (Giovannoni et al., 1988) and has produced a workable phylogenetic scheme based on 16S rRNA gene sequences (Wilmotte \& Herdman, 2001). However, the new technology, when applied to natural systems, has uncovered an overwhelming diversity of uncultured, naturally occurring cyanobacteria (Giovannoni et al., 1990; Hugenholtz et al., 1998). Since the introduction of group-specific primers (Nübel et al., 1997), the technology of molecular sequencing is applicable to the study of organisms in their natural habitats as well as in culture, so it can now be used to reevaluate both the botanical and the bacteriological traditional systems.

In this study, we use a polyphasic approach to address the following questions: (i) Can sequencing and analysis of $16 \mathrm{~S}$ rRNA genes and other molecular tools be applied to the genotypic characterization of preserved botanical type specimens that serve as botanical taxonomic references? If so, (ii) how can the invasiveness of such a procedure be minimized in view of the specimen's historic value? (iii) Can morphological properties be correlated with genotypic characterizations? and (iv) have historic identifications of cyanobacteria by morphological means delivered reliable and reproducible results? For the first time, botanical type specimens are explored and characterized in terms of their genetic as well as phenotypic properties.

\section{METHODS}

Biological materials. For the purposes of this study, dry specimens or exsiccata of cyanobacteria deposited in historic herbaria were obtained on loan from the Institute of Botany, University of Vienna, Herbarium WU and the Swedish Museum of Natural History (Stockholm). The herbarium specimens of cyanobacteria and microscopic algae had been air-dried on paper cards or on mica platelets and stored in small paper bags. Following examination under a dissecting microscope, a small piece (a few $\mathrm{mg}$ ) of the specimen was removed aseptically, the rest was returned to the collection. This procedure complied with the traditional norms of the examination of exsiccata, including type materials. The material removed from the exsiccatum was subdivided into several subsamples.

Sample preparation for microscopy. For light microscopy (LM), a subsample of the exsiccatum was softened for several hours by adding lactic acid or $10 \%$ SDS solution, washed in water and treated with $3 \%$ formaldehyde solution in water and then mounted in glycerol as a semipermanent preparation. The cover slip was framed using commercial nail polish. Photomicrographs were taken using a digital camera (DXM 1200; Nikon) with a microscope (Axioskop 50; Zeiss) equipped with transmitted light, phase-contrast and Nomarski interference contrast (DIC) illumination. Due to the precious nature of the collections, the LM analysis was performed on minimum material. The semipermanent and permanent microscopic slides were saved for later use and were deposited together with the material returned to the collections.

For scanning electron microscopy (SEM), a subsample was soaked in $0 \cdot 1 \mathrm{M}$ sodium phosphate buffer $(\mathrm{pH} 7 \cdot 2)$ for several hours, fixed in $4 \%$ glutaraldehyde in $0 \cdot 1 \mathrm{M}$ sodium phosphate buffer $(\mathrm{pH} 7 \cdot 2)$ and dehydrated through an ethanol-water series. The sample was subsequently critical-point dried in a Balzers Union (CPD 010) apparatus and gold-sputtered (SCD 030, Balzers Union). The specimens were examined with a Zeiss DSM 940 or a Hitachi S-450 SEM operated at 10 or $20 \mathrm{kV}$ and with working distances of 7 to $9 \mathrm{~mm}$. A subsample for transmission electron microscopy (TEM) was soaked in $0 \cdot 1 \mathrm{M}$ sodium phosphate buffer $(\mathrm{pH} \cdot 2)$ or $10 \%$ SDS solution for several days. Further sample preparation and embedding followed the procedure described previously (Surosz \& Palinska, 2004).

Isolation of genomic DNA. A subsample was pulverized and rehydrated with $10-100 \mu \mathrm{l}$ distilled water in a $0.5 \mathrm{ml}$ Eppendorf vial. The slurry was homogenized and exposed to five freeze-thaw cycles, alternating immersion in liquid nitrogen and heating to $60{ }^{\circ} \mathrm{C}$. Robust specimens such as Chroococcus and Nostoc samples were additionally exposed to homogenization with glass beads at 5000 r.p.m. for up to $5 \mathrm{~min}(0 \cdot 10-0 \cdot 11 \mu \mathrm{m}$ diameter glass beads, B. Brown Bideck; Mini-Bead-Beater, Biospec Products). Rehydrated cells and the cell-free supernatant fractions were either used directly in PCR amplifications or the mixture was exposed to 
phenol/chloroform extraction, centrifuged and the aqueous phase was mixed with the 0.6 volume of 2-propanol. DNA was recovered and stored in a minimal volume of sterile, redistilled water.

PCR amplification. For the amplification of approximately 1200 bp of $16 \mathrm{~S}$ rRNA gene fragments, primers described by Nadeau et al. (2001) were used. In some cases, primers and PCR cycling conditions described by Nübel et al. (1997) were additionally applied. The reaction volume was $50 \mu \mathrm{l}$ and contained $1 \times$ REDTaq PCR buffer, $200 \mu \mathrm{M}$ each deoxynucleotide, $100 \mu \mathrm{g}$ BSA, 250 ng each oligonucleotide primer, $2.5 \mathrm{U}$ of REDTaq DNA polymerase (SigmaAldrich) and $5 \mu \mathrm{l}$ DNA extract. To minimize amplification after non-specific annealing of the primers to non-target DNA, polymerase was added to the reaction mixture after the initial denaturation step $\left(5 \mathrm{~min}\right.$ at $94{ }^{\circ} \mathrm{C}$ ) at $80^{\circ} \mathrm{C}$. Thirty-five incubation cycles were performed, each consisting of $1 \mathrm{~min}$ at $94^{\circ} \mathrm{C}, 1 \mathrm{~min}$ at $55^{\circ} \mathrm{C}$ and $1 \mathrm{~min}$ at $72^{\circ} \mathrm{C}$. The presence of PCR products was detected by standard agarose gel electrophoresis and ethidium bromide staining. Purified amplification products (QIAquick PCR purification kit; Qiagen) were commercially, directly sequenced in both directions.

Phylogenetic analysis. 16S rRNA gene sequences obtained from the herbarium samples were aligned with selected GenBank entries with CLUSTAL W (http://www.ebi.ac.uk/clustalw/index.html) at the default configuration and a fragment of approximately $1154 \mathrm{bp}$ (corresponding to Escherichia coli residues 269-1438) was used for the calculation of a neighbour-joining tree (Jukes \& Cantor distance estimation, 2000 bootstraps) with TREECON for Windows $1.3 \mathrm{~b}$ software (Van de Peer \& De Wachter, 1994). E. coli was used as the outgroup.

\section{RESULTS}

Following careful softening and rehydration, the morphological features of the selected dry-preserved cyanobacteria were remarkably well restored. Morphological features were well expressed under the light microscope. Preparations for electron microscopy showed artefacts comparable with the preparation of fresh specimens, although fine structural features were inferior after a prolonged time in the dehydrated state. DNA was preserved and the rehydration enabled satisfactory extraction followed by the application of standard methodologies as used for freshly collected or cultured micro-organisms.

\section{History of the studied exsiccata}

In compliance with the Botanical Code of Nomenclature, the type specimens of cyanobacteria have been deposited in various herbarial collections. In addition, a major effort in the study of algal biodiversity took place at the end of the 19th century, accompanied by widely distributed collections of exsiccata, most prominently by $\mathrm{V}$. B. Wittrock and $\mathrm{O}$. Nordstedt, as Algae aquae dulcis exsiccatae (1880), and F. S. Collins, I. Holden and W. A. Setchell, as Phycotheca borealiamericana (1895-1919). Each of these collections contains numerous cyanobacteria.

Seven specimens from historic exsiccata collections were selected for this study so as to represent different taxonomic divisions of cyanobacteria: Microcystis (Polycystis) aeruginosa Kützing and Chroococcus turgidus Kützing as representatives of coccoid cyanobacteria (Chroococcales; unicellular cyanobacteria, subsection I of Rippka et al., 1979; also Castenholz, 2001); Microcoleus chthonoplastes (Mertens) Zanardini ex Gomont and Trichodesmium erythraeum Ehrenberg ex Bornet et Flahault representing non-heterocystous filamentous cyanobacteria (Oscillatoriales; subsection III of Rippka et al., 1979) and Nostoc muscorum Agardh ex Bornet et Flahault and Nodularia spumigena Bornet et Flahault exemplifying heterocystous filamentous cyanobacteria (Nostocales; subsection IV of Rippka et al., 1979). A natural population of Microcoleus chthonoplastes collected in 1990 in Sečovje salt works near Portorož, Slovenia and air-dried was added for comparison.

Microcystis aeruginosa is a colonial coccoid cyanobacterium commonly forming plankton blooms. Many strains are known for their toxicity (Gorham, 1964; Utkilen et al., 1996). The specimen HUW 226, obtained from the Herbarium of the University of Vienna, was collected by the Hungarian collector Ferdinand Filarszky in 1850 in the small, apparently eutrophic Varosliget Lake in the City Park of Budapest, Hungary.

Chroococcus turgidus, a relatively large coccoid cyanobacterium characterized by cell cleavage and multiple envelopes, was collected by Veit Brecher Wittrock in 1885 in Lake Csorba (Štrbské Pleso), High Tatra Mountains (now in the Slovak Republic) and was distributed as a part of the Wittrock-Nordstedt Algae Exsiccatae collection. We obtained the specimen, designated here as HUW 799, from the herbarium of the University of Vienna, Austria.

Microcoleus chthonoplastes, a non-heterocystous multitrichomous cyanobacterium, is known for its considerable salt tolerance and global distribution (Garcia-Pichel et al., 1996; Karsten, 2002). Herbarium specimen HUW 153 was collected in 1895 by Winthrop Osterhout in a salt marsh near Woods Hole, Massachusetts, USA. We have included for comparison an air-dried sample collected in 1990 by one of us (S.G.) in a saltpan at the Sečovje salt works, near Portorož, Slovenia.

Trichodesmium erythraeum is a marine planktonic, dinitrogen-fixing cyanobacterium commonly forming blooms in tropical oceans. The specimen designated SH A2907 was collected by J. Fellner off the coast of Brazil in 1884 and was distributed as a part of the Wittrock-Nordstedt Algae Exsiccatae collection. We obtained the specimen from the Swedish Museum of Natural History in Stockholm.

Nostoc muscorum is a terrestrial cyanobacterium forming irregular but coherent colonies in a common gel. The herbarium specimen designated HUW 888 was collected by the Austrian phycologist Anton Hansgirg from a wet rock near Lipsic, Bohemia (now Czech Republic).

Nodularia spumigena is a heterocystous planktonic cyanobacterium equipped with intracellular gas vesicles and forming toxic blooms of eutrophic coastal waters, e.g. the Baltic Sea (Mazur \& Pliński, 2003), whereas other forms of 
Table 1. Source histories and reference numbers of studied samples

HUW, Vienna University Herbarium; SH, Swedish Museum of Natural History.

\begin{tabular}{|c|c|c|c|c|c|}
\hline Sample & $\begin{array}{l}\text { GenBank } \\
\text { accession no. }\end{array}$ & $\begin{array}{c}\text { Herbarium } \\
\text { number }\end{array}$ & Habitat & Collection & $\begin{array}{c}\text { Year of collection/ } \\
\text { collector }\end{array}$ \\
\hline Microcystis aeruginosa & DQ460704 & HUW 226 & Varosliget Lake, Hungary & Kryptogamae Exsiccatae & 1885/ V. Wittrock \\
\hline Chroococcus turgidus & DQ460703 & HUW 799 & $\begin{array}{l}\text { Csorba Lake, Tatra } \\
\text { Mountains, Slovakia }\end{array}$ & $\begin{array}{l}\text { Wittrock-Nordstedt: } \\
\text { Algae Exsiccatae }\end{array}$ & 1850/ F. Filarszky \\
\hline Microcoleus chthonoplastes & DQ460701 & 12 & $\begin{array}{l}\text { Hypersaline pond, } \\
\text { Portorož, Slovenia }\end{array}$ & S. Golubic & 1990/ S. Golubic \\
\hline Microcoleus chthonoplastes & DQ460700 & HUW 153 & $\begin{array}{l}\text { Salt marsh, Woods Hole, } \\
\text { USA }\end{array}$ & $\begin{array}{l}\text { Phycotheca Borealis } \\
\text { Americana }\end{array}$ & 1895/ W. Osterhout \\
\hline Trichodesmium erythraeum & DQ460706 & SH A2907 & $\begin{array}{l}\text { Atlantic Ocean, } \\
\text { off Brazil coast }\end{array}$ & $\begin{array}{l}\text { Wittrock-Nordstedt: } \\
\text { Algae Exsiccatae }\end{array}$ & 1884/ J. Fellner \\
\hline Nostoc muscorum & DQ460702 & HUW 888 & $\begin{array}{l}\text { Wet crags, Libsic, } \\
\text { Bohemia }\end{array}$ & $\begin{array}{l}\text { Wittrock-Nordstedt: } \\
\text { Algae Exsiccatae }\end{array}$ & 1886/ A. Hansgirg \\
\hline Nodularia spumigena & DQ460705 & HUW 1307 & $\begin{array}{l}\text { Marsh pools, Harpswell, } \\
\text { Maine, USA }\end{array}$ & $\begin{array}{l}\text { Phycotheca Borealis } \\
\text { Americana }\end{array}$ & 1906/ F. S. Collins \\
\hline
\end{tabular}

Nodularia are benthic and non-toxic (Lyra et al., 2005). Nodularia spumigena var. genuina was collected from a marsh pool at Harpswell, Maine, USA, by Frank Shipley Collins who also issued the Phycotheca Borealis Americana exsiccata collection in collaboration with Isaac Holden and William Albert Setchell. The specimens used in this study and their histories are summarized in Table 1 and illustrated in Fig. 1.

\section{Morphological features of the studied exsiccata}

The herbarium specimen of Microcystis aeruginosa HUW 226 consisted of a dried colony thinly spread over paper and enclosed in a small envelope attached to the herbarium sheet. The colony (Fig. 1a) consisted of an irregularly shaped gelatinous mass in places with distinct large holes densely packed with cells. When observed by LM and SEM (Fig. 1b), the cells appeared nearly spherical, 3-5 $\mu \mathrm{m}$ in diameter and were densely arranged in common mucilage. The cells were pale and showed hardly any auto-fluorescence. The cells produced gas vesicles, consistent with their planktonic mode of life. This could be documented in our sample by TEM (Fig. 1c). In addition to gas vesicles, carboxysomes, cyanophycin and polyphosphate granules could be observed under TEM, but the thylakoids were difficult to discern from packages of gas vesicles.

Chroococcus turgidus HUW 799 formed groups of two to eight cells surrounded by a firm gelatinous envelope as observed by LM (Fig. 1d, e). Cell size ranged from $8 \cdot 3-14 \cdot 6 \mu \mathrm{m}$ in diameter. Fluorescence was weak,

Fig. 1. Morphotypic properties of the studied herbarium specimens. (a-c) Microcystis aeruginosa HUW 226. (a) Clathrate colony with densely packed cells at low magnification (LM). (b) Densely packed cells interconnected by collapsed strings of EPS (SEM). (c) Section through a single cell showing carboxysomes (C), thylakoid membranes (T) and gas vesicles (GV). $(\mathrm{d}-\mathrm{g})$ Chroococcus turgidus HUW 799. (d) Two cells in cleavage-type division within a common thick gelatinous envelope (LM). (e) A colony of 8 cells dividing in 3 dimensions, encapsulated in gelatinous envelopes (LM). (f) A colony of 4 cells after 2 divisions covered by collapsed envelope (SEM). (g) Poorly preserved internal cellular structures of two 4-cell colonies (TEM). (h-k) Microcoleus chthonoplastes HUW 153. (h) Rehydrated trichome showing constrictions at the cross wall and a convexconical end-cell (LM). (i) A bundle of trichomes emerging from the common sheath (SEM). (j) Poorly preserved disjointed cells sectioned at different angles (TEM). (k) Trichome tip in longitudinal section. Thylakoids seen in the conical end-cell (TEM). (I-m) Trichodesmium erythraeum SH A2907. (I) Two rehydrated trichomes, one with constrictions at the cross walls and a well-expressed calyptra on the end-cell. The other showing outlines of packages of collapsed gas-vesicles (LM); ( $\mathrm{m}$ ) Trichomes with traces of EPS over the surface (SEM). $(n-q)$ Nostoc muscorum HUW 888. ( $n$ ) A curved trichome within its gelatinous sheath (LM). (o) Strong auto-fluorescence of cells indicating good preservation of photosynthesis pigments in the cells (epifluorescence LM). (p) Trichomes embedded in common slime layers of the colony (SEM). (q) Ultrathin section of a single cell showing carboxysome (C), polyphosphate granules $(P)$ and thylakoids $(T)$. $(r-t)$ Nodularia spumigena HUW 1307. (r) A single trichome (LM). (s) Trichomes with strong auto-fluorescence (epifluorescence LM). (t) Thin section of a trichome, showing thylakoids $(T)$, carboxysomes (C), cyanophycin (Cy) and polyphosphate granules (P) (TEM). Bars, $10 \mu \mathrm{m}$, except for (a) $100 \mu \mathrm{m}$ and (c, q) $1 \mu \mathrm{m}$. 


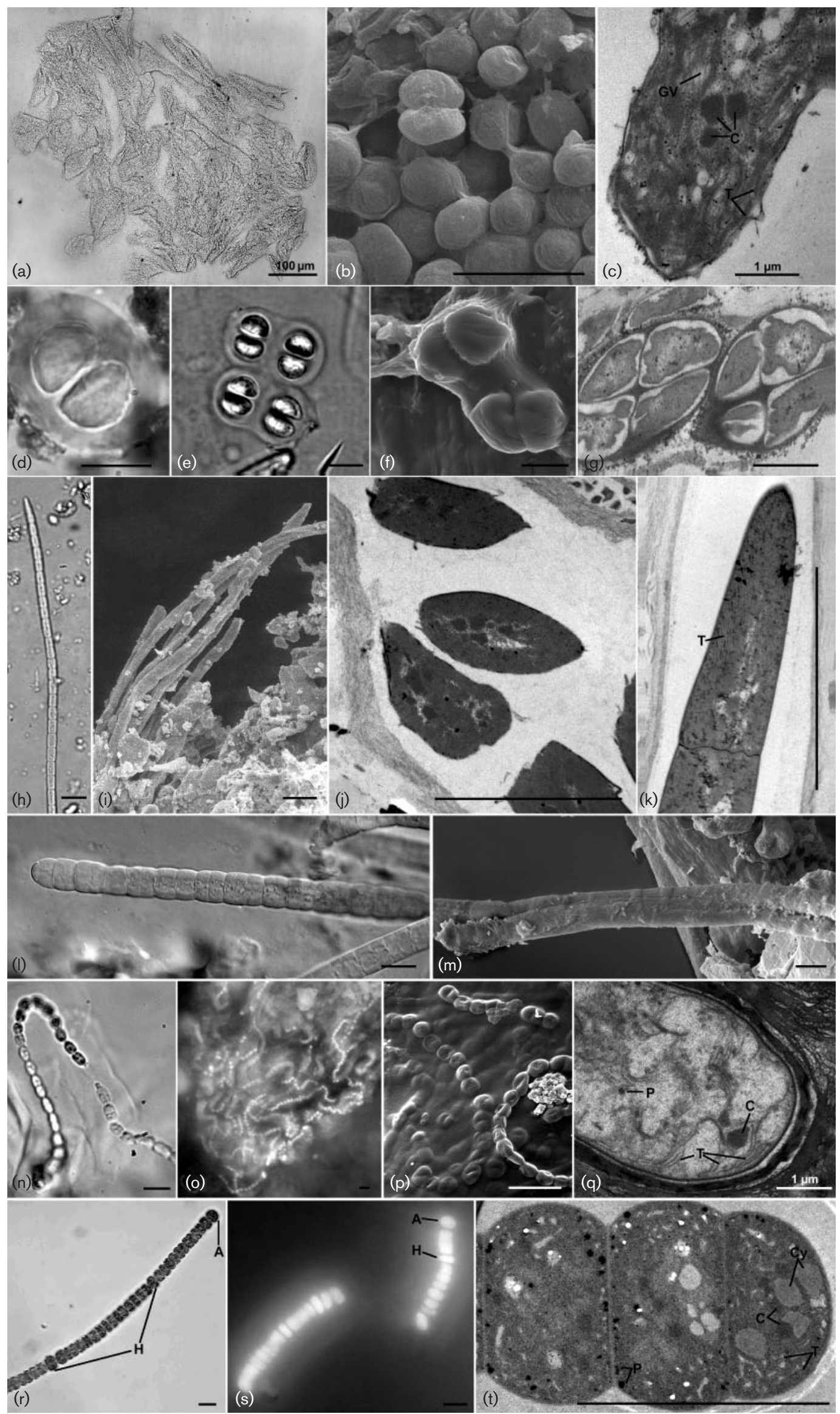


indicating that pigments were at least partially degraded. Air-dried specimens under SEM (Fig. 1f) showed the exterior of a collapsed colony envelope. TEM (Fig. 1g) revealed distinct envelope layers, but shrivelled, partly degraded cell contents without discernable thylakoids, consistent with the weak fluorescence.

Microcoleus chthonoplastes HUW 153 consisted of bundled trichomes, 2.5-6 $\mu \mathrm{m}$ wide, about three times longer than wide and constricted at the cross walls with a conical endcell (Fig. 1h). Filaments are multitrichomous, containing bundles of parallel or intertwined trichomes within a common gelatinous sheath. The SEM image (Fig. 1i) shows a bundle of trichomes emerging from the common sheath. TEM shows trichomes in different states of preservation. Cells disintegrate first by separation at cross walls, but remain embedded in the common sheath which shows a denser exterior and less dense interior texture (Fig. 1j). Wellpreserved end-cells in longitudinal section depicted by TEM show well-defined cross walls and almost intact thylakoids and cellular inclusions (Fig. 1k). The sheath also shows distinct layering. The natural population of $M$. chthonoplastes SEC12 shows similar cell dimensions $(3 \cdot 0-6 \cdot 2 \mu \mathrm{m})$.

On rehydration, Trichodesmium erythraeum SH A2907 presented well-formed straight trichomes with turgescentlooking cells (Fig. 11). Trichome cells showed differentiation in centroplasma and parietal chromatoplasma, but the pigmentation was not preserved. Cells were isodiametric, $8 \cdot 8-11 \cdot 0 \mu \mathrm{m}$ wide and slightly constricted at the cross walls. The end-cell attenuated abruptly to a rounded tip with calyptra. The SEM image (Fig. $1 \mathrm{~m}$ ) shows a thin coating of extracellular gel over the trichomes.

Nostoc muscorum HUW 88 forms macroscopic colonies with trichomes embedded in compact layers of extracellular polysaccharide substances and, when dried, they are clumped together into a hard matrix with a cartilaginous consistency. In addition, the trichomes are torulose, enveloped in individual sheaths (Fig. 1n). Vegetative cells were $2 \cdot 2-4 \cdot 2 \mu \mathrm{m}$ in width and were about $1 \cdot 5$ times longer than wide, this being slightly less than previously described by Geitler (1932). Under the light microscope, a remarkably strong auto-fluorescence indicated that pigments remained preserved in a significant proportion of trichomes (Fig. 10). Heterocysts were round, in intercalary positions and $5 \cdot 0-8 \cdot 0 \mu \mathrm{m}$ wide. Akinets could not be recognized in the material tested. The SEM image shows contorted trichomes embedded in extracellular polymer substances (EPS; Fig. 1p). Under TEM (Fig. 1q), carboxysomes, polyphosphate granules and peripheral, short thylakoid membranes were easily recognizable, as well as envelopes with a fibrillar texture.

Nodularia spumigena var. genuina HUW 1307 showed disklike torulose cells that were shorter than wide and approximately $8-9 \mu \mathrm{m}$ wide (Fig. 1r). Some of the trichomes were enclosed in a thin sheath layer and showed strong auto-fluorescence (Fig. 1s). SEM preparations showed a number of collapsed cells. Heterocysts appeared to be similar in shape to the vegetative cells, but slightly larger $(9 \cdot 6-10 \cdot 8 \mu \mathrm{m})$. Akinets were approximately $11 \mu \mathrm{m}$ in diameter and almost spherical. The TEM image (Fig. 1t) shows numerous cell inclusions and characteristic, wavy peripheral thylakoids.

\section{Phylogenetic relationships of botanical specimens in the 16S rRNA gene sequence tree}

In this study, molecular research on historical herbarium specimens was carried out for the first time. In the course of our studies, we had to take into account the following major problems: (i) the amount of cell material present in the herbarium specimens was limited and, in the case of type specimen material, was particularly precious; (ii) the sample history was very long and unknown and it might have included DNA-damaging events (e.g. during air-drying or later temperature and humidity changes); (iii) due to their environmental origin, the exsiccata samples frequently contained other micro-organisms in addition to the targeted cyanobacterial taxon. However, the use of group-specific primers (Nübel et al., 1997; Nadeau et al., 2001) avoided the introduction of signatures of organotrophic bacteria and fungi which may have been abundant in the samples.

PCR amplification and gene sequencing were successfully applied to all of the cyanobacterial exsiccata examined. $16 \mathrm{~S}$ rRNA gene fragments from 783 bp in Nodularia spumigena to $1200 \mathrm{bp}$ for Chroococcus turgidus (Table 2) were obtained and tested. The taxonomic identities of each of the studied specimens, which were based on morphological determinations over a century ago, were confirmed by the phylogenetic analysis of partial $16 \mathrm{~S}$ rRNA gene sequences.

Microcystis aeruginosa HUW 226 showed $100 \%$ sequence similarity to Microcystis aeruginosa strain UWOCC P3, a non-toxic strain, isolated from freshwater in North America (Doers \& Parker, 1988) and $99.9 \%$ sequence similarity to Microcystis aeruginosa PCC 7806, a toxic strain from the Pasteur Culture Collection. A comparison of the botanical herbarium species of Microcystis aeruginosa HUW 226 and Microcystis aeruginosa PCC 7941, the strain designated by Rippka \& Herdman (1992) as a reference strain for Microcystis aeruginosa, revealed only $98 \cdot 1 \%$ sequence similarity. Otsuka et al. (2001) proposed strain NIES843 ${ }^{\mathrm{T}}$ as the type strain of Microcystis aeruginosa under the Bacteriological Code. The 16S rRNA gene sequence similarity between this strain and Microcystis aeruginosa HUW 226 from the herbarium was $99 \cdot 8 \%$. Based on our present findings, we support the suggestion that the Japanese strain Microcystis aeruginosa NIES $843^{\mathrm{T}}$ should be used as a reference strain for this species instead of Microcystis aeruginosa PCC 7941 (see also Janse et al., 2003).

The 16S rRNA gene sequence of the botanical specimen of Chroococcus turgidus HUW 799 is currently the only sequence of this species available in GenBank. The sequence clustered in the vicinity of the unicellular strains Synechocystis sp. PCC 6803 and Cyanobacterium stanierii 
Table 2. Sequence similarity (\%) of $16 \mathrm{~S}$ rRNA gene fragments of studied historical, herbarium strains to other cyanobacterial sequences from GenBank

Sequence similarity was calculated with the NCBI BLASTN program, version 2.2.10.

\begin{tabular}{|c|c|c|c|}
\hline Herbarium sample & $\begin{array}{l}\text { 16S rRNA gene } \\
\text { fragment length (bp) }\end{array}$ & Similarity (\%) & Close match in GenBank (accession no.) \\
\hline \multirow[t]{3}{*}{ Microcystis aeruginosa HUW 226} & 974 & 100 & Microcystis aeruginosa UWOCC P3 (AF139314) \\
\hline & & $99 \cdot 8$ & Microcystis aeruginosa NIES843 (AB035549) \\
\hline & & $98 \cdot 1$ & Microcystis aeruginosa PCC 7941 (U40340) \\
\hline \multirow[t]{4}{*}{ Chroococcus turgidus HUW 799} & 1210 & $93 \cdot 5$ & Cyanothece PCC 8801 (AF296873) \\
\hline & & $91 \cdot 2$ & Synechocystis sp. PCC 6803 (AB039001) \\
\hline & & $91 \cdot 5$ & Halothece sp. MPI 96P605 (AJ000724) \\
\hline & & $90 \cdot 4$ & Gloeocapsa PCC 73106 (AF132784) \\
\hline \multirow[t]{2}{*}{ Microcoleus chthonoplastes 12} & 1008 & $99 \cdot 9$ & Microcoleus chthonoplastes PCC 7420 (X70770) \\
\hline & 1006 & $99 \cdot 7$ & Microcoleus chthonoplastes HUW 153 (this study) \\
\hline Trichodesmium erythraeum SH A2907 & & $97 \cdot 1$ & Trichodesmium thiebautii (AF013027) \\
\hline \multirow[t]{5}{*}{ Nostoc muscorum HUW 888} & 936 & $98 \cdot 6$ & Nostoc muscorum II (AJ630452) \\
\hline & & $98 \cdot 2$ & Trichormus variabilis KCTC AG10180 (DQ234832) \\
\hline & & $97 \cdot 1$ & Nostoc linckia IAM M-251 (AB074503) \\
\hline & & $96 \cdot 8$ & Nostoc muscorum CENA18 (AY218827) \\
\hline & & $94 \cdot 8$ & Nostoc muscorum CENA61 (AY218828) \\
\hline \multirow[t]{3}{*}{ Nodularia spumigena HUW 1307} & 783 & 100 & Nodularia spumigena NSBR01 (AF268016) \\
\hline & & $99 \cdot 7$ & Nodularia sphaerocarpa UTEX B 2092 (AJ781151) \\
\hline & & $99 \cdot 7$ & Nodularia spumigena PCC 73104 (NSP133184) \\
\hline
\end{tabular}

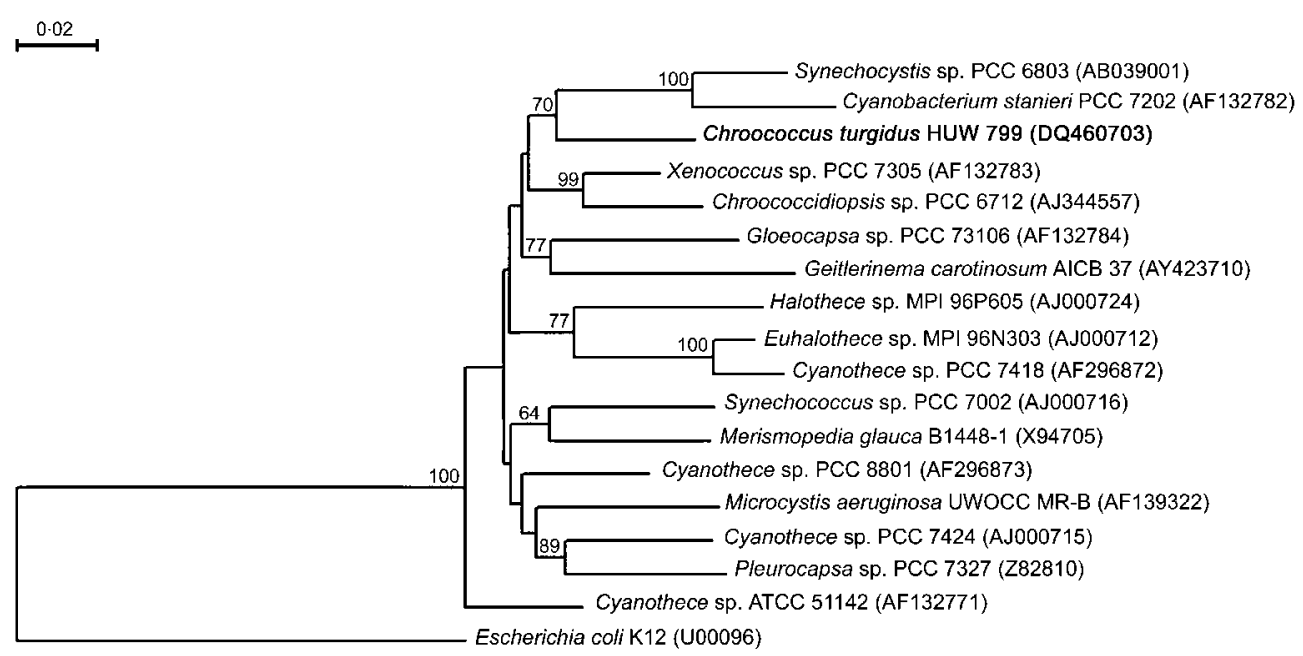

Fig. 2. Neighbour-joining phylogenetic tree of unicellular cyanobacteria showing Chroococcus turgidus HUW 799 (bold type) based on partial 16S rRNA gene sequences of approximately 1154 bp. A bootstrap analysis involving 2000 resamplings was performed and bootstrap values greater than $50 \%$ are given in front of the relevant nodes. Bar, 2 nucleotide substitutions per 100 nucleotides. 
PCC 7202 (Fig. 2). A further representative of the genus Chroococcus in GenBank, Chroococcus submarinus, showed only $92.8 \%$ sequence identity to Chroococcus turgidus HUW 799. Interestingly, the herbarium specimen showed only $90 \cdot 4 \%$ sequence similarity to the $16 \mathrm{~S}$ rRNA gene sequence of Gloeocapsa sp. PCC 73106, even less than the sequence similarity with the 'Halothece' cluster $(91.5 \%)$ described by Garcia-Pichel et al. (1998), thus supporting the existence of Chroococcus and Gloeocapsa as two independent genera. In the traditional botanical literature Chroococcus and Gloeocapsa have been treated as two separate genera (Geitler, 1932; Golubic 1967), but also as a single genus (Gloeocapsa; Elenkin, 1938; Kossinskaya, 1949). Rippka et al. (1979), in their five-section approach, accepted only the genus Gloeocapsa. Later, Waterbury \& Rippka (1989) used the term 'Gloeocapsa group' to accommodate both the genus Gloeocapsa (sensu Rippka et al., 1979) and the large-celled Chroococcus isolates. Wilmotte \& Herdman (2001) suggested a new separation of these two traditional genera on the basis of phylogenetic analyses of $16 \mathrm{~S}$ rRNA gene sequences. Our studies on the botanical herbarium strain Chroococcus turgidus HUW 799 confirmed the present separation of these genera. Here, we propose to use herbarium Chroococcus turgidus HUW 799 as a reference sequence in further comparisons of related strains. Further sequences of phylogenetically and morphologically similar organisms might help to determine whether the grouping of Chroococcus turgidus and the Synechocystis/Cyanobacterium group represent artefacts or true relationships.

For Microcoleus chthonoplastes, both herbarium HUW 153 and 'Portoroz' (12) strains clustered very close to each other ( $99.7 \%$ sequence similarity) and next to Microcoleus chthonoplastes PCC 7420 (99.9\% gene sequence similarity), which was proposed by the Pasteur Culture Collection to be the type strain for this species. That designation was validated in 1996 by Garcia-Pichel et al., whose analyses revealed that strain PCC 7420 fitted phenotypically and by $16 \mathrm{~S}$ rRNA gene sequence in the Microcoleus chthonoplastes taxon. Our results from sequencing the botanically described Microcoleus chthonoplastes species also confirmed this choice. Interestingly, Microcoleus chthonoplastes PCC 7420 was isolated from the same locality (Woods Hole, salt marsh) as the exsiccatum strain investigated here.

The 16S rRNA gene sequences of several different Trichodesmium morphotypes (T. contorum, T. erythraeum, T. hildenbrandtii, T. tenue and T. thiebautii) are known to show a high degree of similarity (Turner, 1997). T. erythraeum SH A2907 also clustered close to a group of public sequences obtained from Trichodesmium Ehrenberg, indicating a close relationship, and fell within the Trichodesmium cluster. The sequence similarity for herbarium T. erythraeum was between $99 \cdot 5$ and $97 \cdot 1 \%$ with the sequences of Trichodesmium sp. (GenBank accession no. X70767) and T. thiebautii (AF091321). Our results again demonstrated the validity of assigning all of these morphotypes to a single genus.
The 16S rRNA gene sequence of Nostoc muscorum HUW 888 showed very high similarity $(98.6 \%)$ to the sequences published by Rajaniemi et al. (2005) for Nostoc muscorum II and I. The 16S rRNA gene sequence of a strain affiliated to Nostoc muscorum CENA61 (GenBank accession no. AY218828) and Nostoc muscorum CENA18 (AY218827) differed significantly from the sequence of the herbarium specimen, showing only $94 \cdot 8$ and $96 \cdot 8 \%$ similarity, respectively. According to the criterion used for genus definition (95\% 16S rRNA gene sequence similarity) by Ludwig et al. (1998), the divergence between the $16 \mathrm{~S}$ rRNA gene sequences from Nostoc muscorum CENA61 and the herbarium Nostoc muscorum HUW 888 (less than 95\% sequence similarity) is high enough for them to be considered as two separate taxonomic units. The use of strains CENA61 and CENA18 in laboratory studies as representatives of Nostoc muscorum is strongly discouraged. Interestingly, Nostoc muscorum HUW 888 from the herbarium had $98.2 \%$ gene sequence similarity to Trichormus variabilis KCTC AG10180. According to Rajaniemi et al. (2005), Trichormus strains were morphologically heterogeneous and did not form a monophyletic cluster. According to the phylogenetic distances summarized by Rajaniemi et al. (2005) and those obtained in this study, Trichormus might actually be polyphyletic. Therefore, more benthic Anabaena, Nostoc and Trichormus strains need to be studied to confirm their phylogenetic positions.

The results of 16S rRNA gene analyses for Nodularia spumigena HUW 1307 were coherent with the recent results published by Lyra et al. (2005), Moffitt et al. (2001) and Lehtimäki et al. (2000). Nodularia spumigena HUW 1307 from the herbarium shared $100 \% 16 \mathrm{~S}$ rRNA gene sequence similarity with the toxic strain Nodularia spumigena NSBR01 isolated from river plankton in Australia. At the same time, the similarity between the herbarium Nodularia spumigena HUW 1307 and Nodularia sphaerocarpa UTEX B 2092 (non-toxic) was as high as $99 \cdot 7 \%$. Nodularia sphaerocarpa UTEX B 2092 was previously assigned to Nodularia spumigena and renamed only recently on the basis of polyphasic studies (Lyra et al., 2005). Furthermore, similarity between the 16S rRNA gene sequence of the herbarium Nodularia and Nodularia spumigena strain PCC 73104, the non-toxic type strain for Nodularia spumigena, was $99 \cdot 7 \%$. According to Lyra et al. $(2001,2005)$ and Moffitt et al. (2001), Nodularia spumigena is a planktonic, toxin-producing organism with extremely high $16 \mathrm{~S}$ rRNA gene sequence similarity values ranging from $98 \cdot 5-100 \%$. Both non-toxic strains (PCC 73104 and UTEX B 2092) were isolated from the same ecological niche (alkaline soil) and shared less gene sequence similarity $(99 \cdot 7 \%)$ with the herbarium Nodularia spumigena than with other planktonic Nodularia. In the case of Nodularia spumigena, the results of $16 \mathrm{~S}$ rRNA gene sequencing may not be sufficient for the selection of a proper reference strain for the species and additional studies of other genes, e.g. those responsible for toxin production and nitrogen fixation (nifH) may be necessary. 


\section{DISCUSSION}

Cyanobacteria or Cyanophyceae ('blue-green algae') have traditionally been classified on the basis of morphological and eco-physiological characteristics and described under the rules of the Botanical Code. This approach was applicable to most morphologically complex members of the group, but faced some serious limitations. Morphological features, such as encapsulation in extracellular polymers (sheaths and envelopes) and even cell dimensions and the prevailing planes of division, are considered to be important taxonomic characters but can often vary with changing environmental conditions (e.g. Dor \& Hornoff, 1985). In addition, similar morphological features have arisen convergently in unrelated organisms which share the same environment (Golubic \& Marcenko, 1965). The classification of morphologically simpler forms, such as, for example, Synechococcus, clearly require the use of distinction criteria other than morphology (Waterbury \& Rippka, 1989; Honda et al., 1999).

The bacteriological approach of studying strains of cyanobacteria in axenic culture has also used phenotypic and predominantly morphological criteria for classification (Rippka et al., 1979). This approach has opened up a wide field of experimental laboratory work with genetically uniform material, including work on molecular phylogeny which established the basic genotypic reference for cyanobacterial diversity (Giovannoni et al., 1988; Wilmotte, 1994; Wilmotte \& Herdman, 2001). The reconstruction of phylogenetic interrelationships based on comparative analyses of 16S rRNA gene sequences has made a significant contribution to the taxonomy of micro-organisms by providing the basis for a natural system. Within a relatively short time, it has also helped to clarify many taxonomic problems with the morphologically more complex protists, metaphyta and metazoa.

However, cultured strains of cyanobacteria often show little resemblance to the corresponding organisms in nature as some phenotypic traits are apparently not expressed in the culture environment (Otsuka et al., 2001). This problem has led to the misidentification of cultures (Palinska et al., 1996; Wilmotte \& Herdman, 2001) and has diminished the value of phylogenetic reconstructions and other analyses of evolutionary interrelationships (Whitton \& Potts, 2000).

The procedure of isolation in culture has proved to be a selective process that excludes a large proportion of microorganisms as 'unculturable' (see Amann et al., 1995) and favours genotypes other than those that dominate natural populations (Ward et al., 1997). Thus, it is now recognized that the axenic cultures available in collections are not representative of the microbial diversity in nature - both in quantity, in terms of the number of axenic strains, and by quality, i.e. by their genotypic identity (Ward et al., 1994).

These considerations question the validity of extrapolating from the results obtained from cultured material to the conditions in nature. This also brings into question the value of the type culture concept as a permanent taxonomic reference. The type culture is expected to continue evolving, thus becoming a 'moving target', which may, over time, significantly depart from the wild-type of its origin, not withstanding the fact that the natural source organism has not been genetically verified in the first place. In contrast, preserved type material (dried, frozen or otherwise) has the advantage of permanently retaining the characteristics of the specimen as they were expressed in nature at the time of collection. In this study, we present evidence that such type materials can be genotypically, as well as phenotypically, characterized and validated.

The introduction of culture-independent molecular methods (Amann et al., 1995) has demonstrated an overwhelming diversity of micro-organisms in nature (Hugenholtz et al., 1998), including a large number of previously unrecognized cyanobacterial taxa (Giovannoni et al., 1990). These finds call for renewed attention to the examination of the diversity of natural populations. There is today ample evidence that cyanobacteria respond to environmental stress by producing water blooms (Codd et al., 1999) in freshwater and marine settings and threaten coral reefs (Paul et al., 2005). Apart from being by themselves a potential environmental hazard, changes in cyanobacterial populations have an important value as indicators of environmental and climatic change. The results of our research show that such changes can be assessed over an extended time period by evaluating the rich accumulated record from historic herbaria. The morphology of the strains used in our studies had been carefully described and correctly identified more than 100 years ago and is confirmed here using different microscopic and genetic approaches. Herbarium collections are perfect subjects for intensive phylogenetic studies, although they have not been previously used for these purposes.

Many important natural history collections have recently been critically under-funded and are in danger of being lost. Our work indicates that these historic collections contain precious information and should be maintained since they are amenable to new technologies and molecular approaches and enable inferences to be made about historic populations. We strongly encourage scientists interested in the phylogeny of cyanobacteria to consult the morphological data and descriptions present in collections of exsiccata for their studies as correct phenotypic descriptions would enormously help the interpretation of phylogenetic trees and avoid misleading information derived from studies that examine only accidentally isolated and misidentified organisms. We anticipate that the results of this study will initiate an evaluation of botanical cyanobacterial type material. We hope that they will stimulate the continuing discussions towards a unified taxonomic treatment of cyanobacteria, both in natural populations and in culture, as started at the International Symposium on Prokaryotic Phototrophs (ISPP) in Tokyo in 2003 and at the 
International Association of the Cyanophytes (IAC) symposium in Luxemburg in 2004 (Oren \& Tindall, 2005; Hoffmann, 2005). Thanks to the molecular data obtained in this study, botanical type species would have the generic definitions required by both codes.

These results should also contribute to discussions on the traditional and newly emerging concepts of species and speciation in prokaryotes (e.g. Rossello-Mora \& Amann, 2001; Cohan, 2002; Gevers et al., 2005).

\section{CONCLUSIONS}

For the first time, polyphasic taxonomic examinations, integrating genotypic and phenotypic studies, have been successfully applied to historical herbarium collections of cyanobacteria. We have introduced molecular data to classically described botanical type species deposited in herbaria. Data gained during this study will allow the first step to be taken towards the unification of the Botanical and Bacteriological Codes for cyanobacteria.

The novel aspect of this study was that a type specimen was explored in terms of its genetic as well as phenotypic properties. This approach opens up the possibility of validating a large volume of ecologically relevant research and connecting the modern polyphasic assessment of diversity with traditional phenotype-based identifications and floral listings. For the first time, the study tested whether micro-organisms identified by phenotypic characters do indeed correspond to the same genotype as traditionally assumed.

\section{ACKNOWLEDGEMENTS}

This work was supported by DFG grant PA 842/1-3. We thank Dr W. Till from the University of Vienna, Herbarium WU and Dr M. Hamnede from the Swedish Museum of Natural History for the loan of exsiccata.

\section{REFERENCES}

Amann, R. I., Ludwig, W. \& Schleifer, K.-H. (1995). Phylogenetic identification and in situ detection of individual microbial cells without cultivation. Microbiol Rev 59, 143-169.

Bornet, E. \& Flahault, C. (1886). Révision des Nostocacées filamenteuses hétérocystées contenues dans les principaux herbiers de France. Ann Sci Nat Bot Paris Ser 37, 323-381 (in French).

Castenholz, R. W. (2001). General characteristics of the cyanobacteria. In Bergey's Manual of Systematic Bacteriology, 2nd edn, vol. 1, pp. 474-487. Edited by D. R. Boone \& R. W. Castenholz. New York: Springer.

Codd, G. A., Bell, S. G., Kaya, K., Ward, C. J., Beattie, K. A. \& Metcalf, J. S. (1999). Cyanobacterial toxins, exposure routes and human health. Eur J Phycol 34, 405-415.

Cohan, F. M. (2002). What are bacterial species? Ann Rev Microbiol 56, 457-487.

Cohn, F. (1875). Untersuchungen über Bakterien. Beiträge Biol Planzen 1, 127-222 (in German).
Doers, M. P. \& Parker, D. L. (1988). Properties of Microcystis aeruginosa and $M$. flos-aquae (Cyanophyta) in culture: taxonomic implications. J Phycol 24, 502-508.

Dor, I. \& Hornoff, M. (1985). Salinity-temperature relations and morphotypes of a mixed population of coccoid cyanobacteria from a hot hypersaline pond in Israel. Mar Ecol 6, 13-25.

Elenkin, A. A. (1938). Sinezelenye vodorosli SSSR Monographia algarum cyanophycearum aquidulcium et terrestrium in finibus URSS inventarum. Pars spec 1, 2, Akad. Moscow-Leningrad: Nauk SSSR.

Garcia-Pichel, F., Prufert-Bebout, L. \& Muyzer, G. (1996). Phenotypic and phylogenetic analyses show Microcoleus chthonoplastes to be a cosmopolitan cyanobacterium. Appl Environ Microbiol 62, 3284-3291.

Garcia-Pichel, F., Nübel, U. \& Muyzer, G. (1998). The phylogeny of unicellular, extremely halotolerant cyanobacteria. Arch Microbiol 169, 469-482.

Geitler, L. (1932). Cyanophyceae. In Dr L. Rabenhorst's Kryptogamen-Flora von Deutschland, Österreich und der Schweiz, vol. XIV. Leipzig: Akademischer Verlag (1985 reprint: KönigsteIn Koeltz Scientific Books).

Gevers, D., Cohan, F. M., Lawrence, J. G. \& 8 other authors (2005). Re-evaluating prokaryotic species. Nat Rev Microbiol 3, 733-739.

Giovannoni, S. J., Turner, S., Olsen, G. J., Barns, J., Lane, D. J. \& Pace, N. R. (1988). Evolutionary relationships among cyanobacteria and green chloroplasts. J Bacteriol 170, 3584-3592.

Giovannoni, S. J., Britschgi, T. B., Moyer, C. L. \& Field, K. G. (1990), Genetic diversity in Sargasso Sea bacterioplankton. Nature 345, 60-63.

Golubic, S. (1967). Zwei wichtige Merkmale zur Abgrenzung der Blaualgengattungen (Two important criteria for delimitation of cyanophyte genera). Schweiz Z Hydrol 29, 175-184 (in German).

Golubic, S. \& Marcenko, E. (1965). Ueber Konvergenzerscheinungen bei Standortsformen der Blaualgen unter extremen Lebensbedingungen (Ecologically induced convergent morphologies in blue-green algae of extreme environments). Schweiz Z Hydrol 27, 207-217 (in German).

Gomont, M. (1892a). Monographie des Oscillariées. Ann Sci Nat Bot Paris 15, 263-368.

Gomont, M. (1892b). Monographie des Oscillariées. Ann Sci Nat Bot Paris 16, 91-264.

Gorham, P. R. (1964). Toxic algae. In Algae and Man, pp. 307-336. Edited by D. F. Jackson. New York: Plenum Publishing Corp.

Hoffmann, L. (2005). Nomenclature of Cyanophyta/Cyanobacteria: roundtable on the unification of the nomenclature under the Botanical and the Bacteriological Codes. Arch Hydrobiol Suppl. 159, 13-29.

Honda, D., Yokota, A. \& Sugiyama, J. (1999). Detection of seven major evolutionary lineages in cyanobacteria based on the $16 \mathrm{~S}$ rRNA gene sequence analysis with new sequences of five marine Synechococcus strains. J Mol Evol 48, 723-739.

Hugenholtz, P., Goebel, B. M. \& Pace, N. R. (1998). Impact of culture-independent studies on the emerging phylogenetic view of bacterial diversity. J Bacteriol 180, 4765-4774.

Janse, I., Meima, M. W., Kardinaal, E. A. \& Zwart, G. (2003). Highresolution differentiation of Cyanobacteria by using rRNA-internal transcribed spacer denaturing gradient gel electrophoresis. Appl Environ Microbiol 69, 6634-6643.

Karsten, U. (2002). Effects of salinity and ultraviolet radiation on the concentration of mycosporine-like amino acids in various isolates of the benthic cyanobacterium Microcoleus chthonoplastes. Phycological Res 50, 129-134.

Komarek, J. \& Anagnostidis, K. (1999). Cyanoprokaryota, 1. Teil: Chroococcales. In Süsswasserflora von Mitteleuropa, Band 19/1, 
pp. 1-548. Edited by H. Ettl, G. Gärtner, H. Heynig \& D. Mollenhauer. Jena: Gustav Fischer Verlag (in German).

Komarek, J. \& Anagnostidis, K. (2005). Cyanoprokaryota. 2. Teil Oscillatoriales. In Süsswasserflora von Mitteleuropa, Band 19/2, pp. 1-757. Edited by B. Büdel, G. Gärtner, L. Krienitz \& M. Schagerl. München: Elsevier Spectrum Akademischer Verlag (in German).

Kossinskaya, E. K. (1949). Opredelitel' Morskikh Sineselenykh Vodorosley [Determination Key of Marine Blue-Green Algae], pp. 1-278 Akad. Moscow-Leningrad: Nauk USSR (in Russian).

Lapage, S. P., Sneath, P. H. A., Lessel, E. F., Skerman, V. B. D., Seeliger, H. P. R. \& Clark, W. A. (editors) (1992). International Code of Nomenclature of Bacteria (1990 Revision). Bacteriological Code. Washington, DC: American Society for Microbiology.

Lehtimäki, J., Lyra, C., Suomalainen, S., Sundman, P., Rouhiainen, L., Paulin, L., Salkinoja-Salonen, M. \& Sivonen, K. (2000). Characterization of Nodularia strains, cyanobacteria from brackish waters, by genotypic and phenotypic methods. Int J Syst Evol Microbiol 50, 1043-1053.

Ludwig, W., Strunk, O., Klugbauer, S., Klugbauer, N., Weizenegger, M., Neumaier, J., Bachleitner, M. \& Schleifer, K. H. (1998). Bacterial phylogeny based on comparative sequence analysis. Electrophoresis 19, 554-568.

Lyra, C., Suomalainen, S., Gugger, M., Vezie, C., Sundman, P., Paulin, L. \& Sivonen, K. (2001). Molecular characterization of planktic cyanobacteria of Anabaena, Aphanizomenon, Microcystis and Planktothrix genera. Int J Syst Evol Microbiol 51, 513-526.

Lyra, C., Laamanen, M., Lehtimäki, J. M., Surakka, A. \& Sivonen, K. (2005). Benthic cyanobacteria of the genus Nodularia are non-toxic, without gas vacuoles, able to glide and genetically more diverse than planktonic Nodularia. Int J Syst Evol Microbiol 55, 555-568.

Mazur, H. \& Pliński, M. (2003). Nodularia spumigena blooms and the occurrence of hepatotoxin in the Gulf of Gdańsk. Oceanologia 45, 305-316.

Moffitt, M. C., Blackburn, S. I. \& Neilan, B. A. (2001). rRNA sequences reflect the ecophysiology and define the toxic cyanobacteria of the genus Nodularia. Int J Syst Evol Microbiol 51, 505-512.

Nadeau, T. L., Milbrandt, E. C. \& Castenholz, R. W. (2001). Evolutionary relationships of cultivated Antarctic oscillatorians (cyanobacteria). J Phycol 37, 650-654.

Nübel, U., Garcia-Pichel, F. \& Muyzer, G. (1997). PCR primers to amplify 16S rRNA genes from Cyanobacteria. Appl Environ Microbiol 63, 3327-3332.

Oren, A. (2004). A proposal for further integration of the cyanobacteria under the Bacteriological Code. Int J Syst Evol Microbiol 54, 1895-1902.

Oren, A. \& Tindall, B. J. (2005). Nomenclature of the cyanophyta/ cyanobacteria/cyanoprokaryotes under the International Code of Nomenclature of Prokaryotes. Arch Hydrobiol Suppl. 159, 39-52.

Otsuka, S., Suda, S., Shibata, S., Oyaizu, H., Matsumoto, S. \& Watanabe, M. M. (2001). A proposal for the unification of five species of the cyanobacterial genus Microcystis Kützing ex Lemmermann 1907 under the Rules of the Bacteriological Code. Int J Syst Evol Microbiol 51, 873-879.

Palinska, K. A., Liesack, W., Rhiel, E. \& Krumbein, W. E. (1996). Phenotype variability of identical genotypes: the need for a combined approach in cyanobacterial taxonomy demonstrated on Merismopedia-like isolates. Arch Microbiol 166, 224-233.

Paul, V. J., Thacker, R. W., Banks, K. \& Golubic, S. (2005). Benthic cyanobacterial bloom impact the reefs of South Florida (Broward County USA). Coral Reefs 24, 693-697.

Rajaniemi, P., Hrouzek, P., Kastovska, K., Willame, R., Rantala, A., Hoffmann, L., Komarek, J. \& Sivonen, K. (2005). Phylogenetic and morphological evaluation of the genera Anabaena, Aphanizomenon, Trichormus and Nostoc (Nostocales, Cyanobacteria). Int J Syst Evol Microbiol 55, 11-26.

Rippka, R. \& Herdman, M. (1992). Part 4: Strain List. In Pasteur Culture Collection of Cyanobacteria, Catalogue \& Taxonomic Handbook, vol. I: Catalogue of Strains (1992/1993), pp. 12-59. Edited by R. Rippka \& M. Herdman. Paris: Institut Pasteur.

Rippka, R., Deruelles, J., Waterbury, J. B., Herdman, M. \& Stanier, R. Y. (1979). Generic assignments, strain histories and properties of pure cultures of cyanobacteria. J Gen Microbiol 111, 1-61.

Rossello-Mora, R. \& Amann, R. (2001). The species concept for prokaryotes. FEMS Microbiol Rev 25, 39-67.

Stanier, R. Y. (1977). Position of Cyanobacteria in the world of phototrophs. Carlsberg Res Comm 42, 77-98.

Stanier, R. Y. \& Cohen-Bazire, G. (1977). Phototrophic prokaryotes: the cyanobacteria. Annu Rev Microbiol 31, 225-274.

Stanier, R. Y., Sistrom, W. R., Hansen, T. A. \& 9 other authors (1978). Proposal to place the nomenclature of the cyanobacteria (blue-green algae) under the rules of the International Code of Nomenclature of Bacteria. Int J Syst Bacteriol 28, 335-336.

Surosz, W. \& Palinska, K. A. (2004). Effects of heavy metal stress on cyanobacterium Anabaena flos-aquae. Arch Environ Contam Toxicol 48, 40-48.

Turner, S. (1997). Molecular systematics of oxygenic photosynthetic bacteria. Plant Syst Evol Suppl. 11, 13-52.

Utkilen, H., Skulberg, R., Underdal, B., Gjølme, N., Skulberg, R. \& Kotai, J. (1996). The rise and fall of a toxigenic population of Microcystis aeruginosa (cyanophyceae/cyanobacteria) - a decade of observations in Lake Akersvatnet, Norway. Phycologia 35, 189-197.

Van de Peer, Y. \& De Wachter, R. (1994). TREECON for Windows: a software package for the construction and drawing of evolutionary trees for the Microsoft Windows environment. Comput Appl Biosci 10, 569-570.

Ward, D. M., Ferris, M. J., Nold, S. C., Bateson, M. M., Kopkczynski, E. D. \& Ruff-Roberts, A. L. (1994). Species diversity in hot spring microbial mats as revealed by both molecular and enrichment culture approach - relationship between biodiversity and community structure. In Microbial Mats, Structure, Development and Environmental Significance (NATO ASI Series, G.35), pp. 33-44. Edited by L. J. Stal \& P. Caumette. Heidelberg: Springer.

Ward, D. M., Santegoeds, C. M., Nold, S. C., Ramsing, N. B., Ferris, M. J. \& Bateson, M. M. (1997). Biodiversity within hot spring microbial mat communities: molecular monitoring of enrichment cultures. Antonie van Leeuwenhoek 71, 143-150.

Waterbury, J. B. \& Rippka, R. (1989). Subsection I. Order Chroococcales Wettstein 1924, emend. Rippka et al., 1979. In Bergey's Manual of Systematic Bacteriology, vol. 3, pp. 1728-1746. Edited by J. T. Staley, M. P. Bryant, N. Pfennig \& J. G. Holt. Baltimore: Williams \& Wilkins.

Waterbury, J. B. \& Stanier, R. Y. (1977). Two unicellular cyanobacteria which reproduce by budding. Arch Microbiol 115, 249-257.

Whitton, B. A. \& Potts, M. (2000). Introduction to the cyanobacteria. In The Ecology of Cyanobacteria, pp. 1-11. Edited by B. A. Whitton \& M. Potts. Dordrecht: Kluwer Academic.

Wilmotte, A. (1994). Molecular evolution and taxonomy of the Cyanobacteria. In The Molecular Biology of Cyanobacteria, pp 1-25. Edited by D. A. Bryant. Dordrecht: Kluwer Academic Publishers.

Wilmotte, A. \& Herdman, M. (2001). Phylogenetic relationships among the Cyanobacteria based on 16S rRNA sequences. In Bergey's Manual of Systematic Bacteriology, 2nd edn, vol. 1, pp. 487-493. Edited by D. R. Boone \& R. W. Castenholz. New York: Springer.

Woese, C. R. (1987). Bacterial evolution. Microbiol Rev 51, 221-271. 